UDK 528.61:550.381

\title{
WMM-00 GEOMAGNETINIO LAUKO MODELIO LIETUVOS TERITORIJOJE TIKSLUMO TYRIMAS
}

\author{
Romuald Obuchovski \\ Geodezijos ir kadastro katedra, Vilniaus Gedimino technikos universitetas, \\ Saulètekio al. 11, LT-10223 Vilnius-40, el. paštas: gkk@ap.vtu.lt
}

Iteikta 200312 01; priimta 20040210

\begin{abstract}
Santrauka. Matavimų technikos lygis teikia galimybę detaliau ištirti Žemès paviršiuje vykstančius fizikinius procesus. Atliekant geomagnetinio lauko palydovinius stebèjimus, tikslius ir nuolatinius matavimus magnetinèse observatorijose, geomagnetinius lauko matavimus amžių variacijų punktuose, aeromagnetinius ir jūru matavimus sukaupta nemažai informacijos apie geomagnetinio lauko išsidèstymą erdvejje ir jo kitimą laike. Tokios informacijos gausybė suteikia galimybę matematiškai modeliuoti geomagnetini lauką. Geomagnetinio lauko modeliai plačiai taikomi oro navigacijos, karybos bei civiliniams tikslams. Straipsnyje įvertintas WMM-00 (World Magnetic Model) geomagnetinio lauko modelio tikslumas Lietuvos teritorijoje. Pagal ši modeli nustatomos topografiniu 1:50 000 mastelio žemèlapių magnetinès deklinacijos reikšmès. Šio modelio duomenys taip pat naudojami aviacijoje skaičiuojant aerouosto irrenginių magnetinio azimuto ir magnetinès deklinacijos reikšmes.
\end{abstract}

Raktažodžiai: Žemės magnetinis laukas, geomagnetinio lauko modeliai.

\section{Ivadas}

Žemės ir kosminès erdvès sąveika sukuria aplink Žemę magnetini lauką. Žemei sukantis apie savo aší, jos mantija su kietaja pluta, slysdamos branduolio išoriniu sluoksniu, sukasi šiek tiek greičiau negu vidinis branduolys, todèl branduolio elektronu ir mantijos bei plutos elektronų greičiai skiriasi. Toks elektronų judèjimas sukuria gamtini srovès generatorių (dinama), šis savo ruožtu - magnetini lauką, panašiai kaip indukcine rite tekanti elektros srovè. Magnetinio lauko, kuri sukuria Žemès gelmès, stiprumas lygus iki $95 \%$ viso Žemès paviršiuje esamo magnetinio lauko stiprumo. Kiti apie $5 \%$ - tai Saulès spinduliuojamų elektringujų dalelių srautas, elektringosios dalelès, judančios jonosferoje ir magnetosferoje, bei isimagnetinusios Žemès plutos uolienos [1].

Žemès magnetinis laukas laike nuolat nevienodai kinta. Ivairūs vartotojai reikalauja patikimos informacijos apie geomagnetinio lauko elementų erdvejje reikšmiu pasiskirstymą ir jų pokyti laike. Svarbu taip pat prognozuoti lauko pokyčius, t. y. kokios lauko reikšmès bus bet kuriame taške po tam tikro laikotarpio. Nuolat matuojant magnetini lauką galima nustatyti lauko pokyčius ištisus metus. Tokie matavimai atliekami magnetinèse observatorijose. Geomagnetinio lauko tyrimams taip pat taikomi palydoviniai stebejjimai, atliekami matavimai iš lèktuvų, jūriniai matavimai. Panaudojant šiuos duomenis yra galimybe matematiškai atvaizduoti Žemès magnetini lauką ir jo pokyti, t. y. sukurti magnetinio lauko modeli. Beje, tikrasis geomagnetinis laukas skiriasi nuo teorinio lauko, kuri matematiškai aprašo magnetiniai modeliai.
Straipsnyje nagrinejjamas WMM-00 geomagnetinio lauko Lietuvos teritorijoje modelio tikslumas. „Modelio tikslumas“ suprantama tai, kaip tiksliai turimas geomagnetinis modelis nusako realią geomagnetinę situaciją. Apžvelgiami geomagnetiniam laukui modeliuoti naudoti duomenys, modeliavimo technologija, sudarinejjant WMM-00 modelị. Šis modelis skirtas oro bei jūros navigacijos tikslams. WMM modelị sukūrè Didžiosios Britanijos (BGS) ir JAV (USGS) geologai. Didžiosios Britanijos Gynybos ministerija, JAV Gynybos departamentas, NATO organizacija ir Pasaulio hidrografijos biuras (WHO) WMM modeli prièmė kaip standartini navigacijos poreikiams skirtą modeli. Jis taip pat plačiai taikomas civilinèse navigacinèse sistemose. Lietuvoje pagal ši modeli skaičiuojamos magnetinès deklinacijos reikšmès. Jos pateikiamos 1:50 000 mastelio topografiniuose žemèlapiuose bei skaičiuojant aerouosto ịrenginių magnetinị azimutą ir magnetinę deklinaciją.

\section{Kuriant magnetinị modelị naudoti duomenys}

Sudarant magnetini modeli naudotasi šių šaltinių duomenimis [3]:

- Magnetinių observatorijų stebejjimų;

- Palydovinių stebėjimų;

- Geomagnetinių matavimų amžių variacijų punktuose;

- Aeromagnetinių ir jūrų geomagnetinių matavimu.

Magnetinèse observatorijose Žemès magnetinio lauko parametrai matuojami kas minutę arba trumpesniais 
laiko intervalais. Observatorijos vieta parenkama plote, kuriame nėra magnetinị lauką trikdančių šaltinių poveikių. $B G S$ ir USGS organizacijoms pavaldžios devyniolika magnetiniu observatoriju Atlanto vandenyne, Didžiojoje Britanijoje, Folklandų salose, Kanadoje, Aliaskoje, Ramiajame vandenyne. Naudojami taip pat duomenys iš observatorijų, itrauktų i Intermagnet (International Real-time Magnetic Observatory Network) asociaciją. Šios asociacijos tikslas - sukurti vientisą globaluji magnetinių observatorijų tinklą, priimti modernius matavimu ir registracijos specifikaciju standartus, palengvinti keitimąsi geomagnetiniais duomenimis realiame laike. Iš viso modeliavimui panaudota 190 observatorijų duomenys.

Palydoviniai duomenys teikia globalią informaciją apie geomagnetini lauką per santykinai trumpa laikotarpi. WMM serijos modeliuose pagrindinai naudojami dvieju palydovų matavimų duomenys: Danų palydovo Ørsted, paleisto $1999 \mathrm{~m}$., bei POGS palydovo, paleisto $1990 \mathrm{~m}$. (duomenys kaupti iki 1993 m.).

Amžių variacijų punktai - tai vietovejje įtvirtinti punktai, kuriuose periodiškai, dažniausiai kas 2-4 metai, dideliu tikslumu išmatuojami geomagnetinio lauko parametrai [2]. Tokių matavimų tikslas - sekti geomagnetinio lauko amžių pokyčius. Šie duomenys papildo magnetinių observatorijų duomenis apie amžių pokyčius. Kuriant modeli naudotasi i Pasaulio duomenu centrą (World Data Centre) ittrauktais amžių variacijų punktais.

Aeromagnetiniai ir jūru geomagnetiniai matavimai tikslingi Žemès plutos lauko apžvalginei analizei atlikti. Dèl sudètingu matavimų procedūrų, aeromagnetiniais matavimais nustatomas tik magnetinio lauko jègos intensyvumas. Dažniausiai tokie matavimai atliekami virš vandenynu.

\section{WMM-00 geomagnetinis modelis}

Taikant globalius ir regioninius Žemès magnetinio lauko modelius skaičiuojamos magnetinio lauko elementų reikšmės kaip padėties ir laiko funkcija [3-5].

Žemès magnetini lauką nusako vektorius $B$, priklausantis nuo taško atstumo iki sferos centro $-r$ ir laiko $-t$. Geomagnetini lauką sudaro trys pagrindiniai šaltiniai: pagrindinis Žemès magnetinis laukas, susidaręs Žemès viduje $\left(B_{m}\right)$, Žemès plutos laukas, susidaręs dèl lokaliujų uolienų issimagnetinimo $\left(B_{c}\right)$ ir trikdžių laukas, kuri sukelia elektros srovès, tekančios aukštutinèje atmosferoje ir magnetosferoje. Taip indukuojama elektros srovè jūros ir žemès paviršiuose $\left(B_{d}\right)$. Žemès magnetini lauką galima išreikšti tokia forma:

$$
B(r, t)=B_{m}(r, t)+B_{c}(r)+B_{d}(r, t) .
$$

Pagrindinis Žemès magnetinis laukas $B_{m}$ yra iki $95 \%$ viso Žemès paviršiaus magnetinio lauko stiprumo ir lètai kinta laike. Jo kitimas vadinamas amžių variacija. Yra daug ivairių pagrindinio lauko kilmès hipotezių, viena iš ju - hidromagnetinio generatoriaus hipotezè. Manoma, kad elektrai laidžiame ir skystame Žemès branduolyje vyksta intensyvūs ir sudètingi judesiai, sukeliantys magnetinio lauko saviindukciją. Žemès magnetinis laukas stipriausias prie magnetinių polių, o silpniausias pusiaujo srityje.

Dèl Žemès plutos uolienų imagnetinimo $B_{c}$ padidejja magnetinio lauko stiprumas, susidaro lokaliosios variacijos, tačiau mažesnès nei pagrindinio lauko stiprumas. Kuriant Žemès magnetini modeli buvo laikoma, kad lokaliujų uolienų imagnetinimas laike nekinta.

Kintamaji Žemès magnetini lauką $B_{d}$ sukelia išoriniai šaltiniai Žemès magnetosferoje ir jonosferoje, o labiausiai - Saulès vèjas. Magnetosfera yra erdvès sritis apie Žemę, kurioje jaučiamas Žemès magnetinis laukas. Ji nesimetriška, nes ją veikia Saulès vejjas. Dèl Saulès vëjo poveikio šiek tiek pakinta priežeminis magnetinis laukas. Kai kurie pokyčiai, pavyzdžiui, paros svyravimai, būna reguliarūs, o kiti (magnetinès audros) nereguliarūs.

Žemès paviršiuje magnetinis laukas $B$ nusakomas kaip neigiamas skaliarinio potencialo gradientas $V$ [3-5]:

$$
B=-\nabla V(r, \theta, \lambda, t),
$$

kuris, tenkina Laplaso lygtị:

$$
\nabla^{2} V(r, \theta, \lambda, t)=0
$$

čia $(r, \theta, \lambda)$ yra sferinès koordinatès: $r$ - spindulys nuo sferos centro, $\theta$ - geocentrinè platuma, $\lambda$ - geocentrinè ilguma, $t$ - laikas. Skaliarinis potencialas - tai išorinio ir vidinio potencialų suma:

$$
V=V_{i n t}+V_{e x t},
$$

čia $V_{i n t}$ - vidinis skaliarinis potencialas, $V_{\text {ext }}-$ išorinis skaliarinis potencialas.

Laplaso lygtis pagal sferines koordinates aprašoma:

$$
\begin{aligned}
& V(r, \theta, \lambda, t)=a \sum_{n=1}^{n i_{\max }}\left(\frac{a}{r}\right)^{n+1} \sum_{m=0}^{n}\left(g_{n}^{m}(t) \cdot \cos m \lambda+h_{n}^{m}(t)\right. \\
& \cdot \sin m \lambda) \cdot P_{n}^{m}(\theta)+a \sum_{n=1}^{n e_{\max }}\left(\frac{r}{a}\right)^{n} \sum_{m=0}^{n}\left(q_{n}^{m}(t) \cdot \cos m \lambda+\right. \\
& \left.+s_{n}^{m}(t) \cdot \sin m \lambda\right) \cdot P_{n}^{m}(\theta)
\end{aligned}
$$

čia $a$ - Žemès vidutinis spindulys $(6371,2), g_{n}^{m}(t)$ ir $h_{n}^{m}(t)$ - vidiniai Gauso koeficientai laiko momentu $t$; $q_{n}^{m}(t)$ ir $s_{n}^{m}(t)$ - išoriniai Gauso koeficientai laiko momentu $t ; P_{n}^{m}(\theta)$ - Schmidto normalizuotoji ir Lagranžo daugianarès $m$ eilès ir $n$ laipsnio sferinès harmoninès funkcijos. Gauso koeficientai lètai kinta laike ir išreiškiami Teiloro lygtimi:

$$
g_{n}^{m}(t)=g_{n}^{m}\left(T_{\text {Epoch }}\right)+\dot{g}_{n}^{m}\left(t-T_{\text {Epoch }}\right),
$$




$$
T_{\text {Epoch }} \leq t \leq T_{\text {Epoch }}+5
$$

$$
\begin{aligned}
& h_{n}^{m}(t)=h_{n}^{m}\left(T_{\text {Epoch }}\right)+\dot{h_{n}^{m}}\left(t-T_{\text {Epoch }}\right), \\
& T_{\text {Epoch }} \leq t \leq T_{\text {Epoch }}+5
\end{aligned}
$$

$T_{\text {Epoch }}$ - tai pagrindinè modelio epocha, kuri WMM-00 yra 2000,0 m.; $g_{n}^{m}\left(T_{\text {Epoch }}\right)$ ir $h_{n}^{m}\left(T_{\text {Epoch }}\right)-$ pagrindinio lauko modelio Gauso pagrindinès epochos koeficientai; $\dot{g_{n}^{m}}$ ir $\dot{h_{n}^{m}}$ - Gauso koeficientų variacijos per 5 metus nuo pagrindinès epochos pradžios. Laikoma, kad išoriniai parametrai nekinta laike:

$$
\begin{array}{ll}
q_{n}^{m}(t)=q_{n}^{m} & t \approx t_{0} \\
s_{n}^{m}(t)=s_{n}^{m} & t \approx t_{0} .
\end{array}
$$

Praktikoje pagrindinis laukas, išorinis laukas ir lauko pokytis modeliuojami atskirai. Vidinio lauko rodiklis $n i_{\max }=12$, išorinio lauko $n e_{\max }=5$ ir pagrindinio lauko amžiu variacijos $n_{\max }=8$. Išreiškę lygtị (5) pagal $r, \theta$ ir $\lambda$ gausime:

$$
\begin{aligned}
& B_{r}=-\frac{\partial V}{\partial r}=\sum_{n=1}^{12}(n+1)\left(\frac{a}{r}\right)^{n+2} \sum_{m=0}^{n}\left(g_{n}^{m} \cdot \cos m \lambda+h_{n}^{m} .\right. \\
& \cdot \sin m \lambda) \cdot P_{n}^{m}(\theta)-\sum_{n=1}^{5} n\left(\frac{r}{a}\right)^{n-1} \sum_{m=0}^{n}\left(q_{n}^{m} \cdot \cos m \lambda+s_{n}^{m} \cdot\right. \\
& \cdot \sin m \lambda) \cdot P_{n}^{m}(\theta), \\
& B_{\theta}=-\frac{1}{r} \frac{\partial V}{\partial \theta}=-\sum_{n=1}^{12}\left(\frac{a}{r}\right)^{n+2} \sum_{m=0}^{n}\left(g_{n}^{m} \cdot \cos m \lambda+h_{n}^{m} \cdot\right. \\
& \cdot \sin m \lambda) \cdot \frac{d P_{n}^{m}(\theta)}{d \theta}-\sum_{n=1}^{5}\left(\frac{r}{a}\right)^{n-1} \sum_{m=0}^{n}\left(q_{n}^{m} \cdot \cos m \lambda+\right. \\
& \left.+s_{n}^{m} \cdot \sin m \lambda\right) \cdot \frac{d P_{n}^{m}(\theta)}{d \theta}, \\
& B_{\lambda}=-\frac{1}{r \sin \theta \partial \lambda} \frac{\partial V}{\partial \lambda}=\frac{1}{\sin \theta} \sum_{n=1}^{12}\left(\frac{a}{r}\right)^{n+2} \sum_{m=0}^{n} m \cdot\left(g_{n}^{m} \cdot\right. \\
& \left.\cdot \sin m \lambda-h_{n}^{m} \cdot \cos m \lambda\right) \cdot P_{n}^{m}(\theta)+\frac{1}{\sin \theta} \sum_{n=1}^{5}\left(\frac{r}{a}\right)^{n-1} \sum_{m=0}^{n} m . \\
& \cdot\left(q_{n}^{m} \cdot \sin m \lambda-s_{n}^{m} \cdot \cos m \lambda\right) \cdot P_{n}^{m}(\theta),
\end{aligned}
$$

ir amžių variacijų lygtis:

$$
\begin{aligned}
& \dot{B}_{r}=-\frac{\partial \dot{V}}{\partial r}=\sum_{n=1}^{8}(n+1)\left(\frac{a}{r}\right)^{n+2} \sum_{m=0}^{n}\left(g_{n}^{m} \cdot \cos m \lambda+\dot{h}_{n}^{m} .\right. \\
& \cdot \sin m \lambda) \cdot P_{n}^{m}(\theta)
\end{aligned}
$$

$$
\dot{B}_{\theta}=-\frac{1}{r} \frac{\partial \dot{V}}{\partial \theta}=-\sum_{n=1}^{8}\left(\frac{a}{r}\right)^{n+2} \sum_{m=0}^{n}\left(\dot{g}_{n}^{m} \cdot \cos m \lambda+\dot{h_{n}^{m}}\right.
$$

$$
\begin{aligned}
& \cdot \sin m \lambda) \cdot \frac{d P_{n}^{m}(\theta)}{d \theta}, \\
& \dot{B}_{\lambda}=-\frac{1}{r \sin \theta} \frac{\partial \dot{V}}{\partial \lambda}=\frac{1}{\sin \theta} \sum_{n=1}^{8}\left(\frac{a}{r}\right)^{n+2} \sum_{m=0}^{n} m \cdot\left(\dot{g}_{n}^{m} .\right. \\
& \left.\cdot \sin m \lambda-\dot{h}_{n}^{m} \cdot \cos m \lambda\right) \cdot P_{n}^{m}(\theta) .
\end{aligned}
$$

Modelio skaičiavimams įvedami punkto padèties duomenys - geodezinė platuma $\theta^{\prime}$, geodezinè ilguma $\lambda$ ir geodezinis aukštis $h$-perskaičiuojami i geocentrines koordinates $(r, \theta, \lambda)$ :

$$
\operatorname{tg} \theta=\frac{\left(A^{2} \sin ^{2} \theta^{\prime}+K^{2} \cos ^{2} \theta^{\prime}\right)^{\frac{1}{2}} h+A^{2}}{\left(A^{2} \sin ^{2} \theta^{\prime}+K^{2} \cos ^{2} \theta^{\prime}\right)^{\frac{1}{2}} h+K^{2}} \cdot \operatorname{tg} \theta^{\prime}
$$

ir

$$
\begin{aligned}
& r^{2}=h^{2}+2 h\left(A^{2} \sin ^{2} \theta^{\prime}+K^{2} \cos ^{2} \theta^{\prime}\right)^{\frac{1}{2}}+ \\
& +\frac{A^{4} \sin ^{2} \theta^{\prime}+K^{4} \cos ^{2} \theta^{\prime}}{A^{2} \sin ^{2} \theta^{\prime}+K^{2} \cos ^{2} \theta^{\prime}},
\end{aligned}
$$

čia $A$ yra sferoido pusiaujinis spindulys, $K-$ polinis spindulys.

Pagal $B_{\theta}, \quad B_{\lambda}$ ir $B_{r}$ geocentrines koordinates skaičiuojami $X, Y$ ir $Z$ magnetiniai elementai:

$$
\begin{aligned}
& X=-B_{\theta} \cos \psi-B_{r} \sin \psi, \\
& Y=B_{\lambda}, \\
& Z=B_{\theta} \sin \psi-B_{r} \cos \psi,
\end{aligned}
$$

čia $\psi$ - tai geocentrinès ir geodezinès platumos skirtumas:

$$
\psi=\theta-\theta^{\prime}
$$

Pagal ryšio lygtis apskaičiuojamos ir kitų magnetinio lauko elementų reikšmès:

$$
\begin{aligned}
& D=\operatorname{arctg} \frac{Y}{X}, \\
& I=\operatorname{arctg} \frac{Z}{H}, \\
& F=\sqrt{H^{2}+Z^{2}}, \\
& H=\sqrt{X^{2}+Y^{2}} .
\end{aligned}
$$

2000,5 m. epochos pagrindinio magnetinio lauko Gauso koeficientai bei 2000,0-2005,0 m. epochų amžių pokyčiu $(S V)$ koeficientai pateikti 1 lentelejje. 
1 lentelè. 2000,0 m. epochos Gauso koeficientai bei 2000,0-2005,0 m. epochų amžių pokyčių (SV) koeficientai

Table 1. Gauss main-field coefficients for 2000,0 and secular-variation (SV) coefficients for 2000,0-2005,0 epoch

\begin{tabular}{|c|c|c|c|c|c|c|c|c|c|c|c|c|c|c|}
\hline$g / h$ & $n$ & $m$ & 2000 & $\dot{g} / \dot{h}$ & $g / h$ & $n$ & $m$ & 2000 & $\dot{g} / \dot{h}$ & $g / h$ & $n$ & $m$ & 2000 & $\dot{g} / \dot{h}$ \\
\hline$g$ & 1 & 0 & -29616 & 14,7 & $g$ & 7 & 1 & $\begin{array}{l}-73,9 \\
\end{array}$ & $-0,8$ & $h$ & 9 & 9 & 3,2 & 0 \\
\hline$g$ & 1 & 1 & $-1722,7$ & 11,1 & $h$ & 7 & 1 & $\begin{array}{l}-62,3 \\
\end{array}$ & 1,4 & $g$ & 10 & 0 & $-2,2$ & 0 \\
\hline$h$ & 1 & 1 & 5194,5 & $-20,4$ & $g$ & 7 & 2 & 2,2 & $-0,2$ & $g$ & 10 & 1 & $-5,7$ & 0 \\
\hline$g$ & 2 & 0 & $-2266,7$ & $\begin{array}{l}-13,6 \\
\end{array}$ & $h$ & 7 & 2 & $-24,5$ & 0,2 & $h$ & 10 & 1 & 0,9 & 0 \\
\hline$g$ & 2 & 1 & 3070,2 & $-0,7$ & $g$ & 7 & 3 & 35,7 & 1,1 & $g$ & 10 & 2 & 1,6 & 0 \\
\hline$\frac{\delta}{h}$ & 2 & 1 & $-2484,8$ & $-21,5$ & $\frac{s}{h}$ & 7 & 3 & 8,9 & 0,7 & $h$ & 10 & 2 & $-0,7$ & 0 \\
\hline$g$ & 2 & 2 & 1677,6 & $-1,8$ & $g$ & 7 & 4 & 7,3 & 0,4 & $g$ & 10 & 3 & $-3,7$ & 0 \\
\hline$h$ & 2 & 2 & $-467,9$ & $-9,6$ & $h$ & 7 & 4 & 23,4 & 0,4 & $h$ & 10 & 3 & 3,9 & 0 \\
\hline$g$ & 3 & 0 & 1322,4 & 0,3 & $g$ & 7 & 5 & 5,2 & 0 & $g$ & 10 & 4 & $-0,6$ & 0 \\
\hline$g$ & 3 & 1 & $-2291,5$ & $-4,3$ & $h$ & 7 & 5 & 15 & $-0,3$ & $h$ & 10 & 4 & 4,8 & 0 \\
\hline$h$ & 3 & 1 & $-224,7$ & 6,4 & $g$ & 7 & 6 & 8,4 & $-0,2$ & $g$ & 10 & 5 & 4,1 & 0 \\
\hline$g$ & 3 & 2 & 1255,9 & 0,9 & $h$ & 7 & 6 & $-27,6$ & $-0,8$ & $h$ & 10 & 5 & $-5,3$ & 0 \\
\hline$h$ & 3 & 2 & 293 & $-1,3$ & $g$ & 7 & 7 & $-1,5$ & $-0,2$ & $g$ & 10 & 6 & 2,2 & 0 \\
\hline$g$ & 3 & 3 & 724,8 & $-8,4$ & $h$ & 7 & 7 & $-7,8$ & $-0,1$ & $h$ & 10 & 6 & -1 & 0 \\
\hline$h$ & 3 & 3 & $-486,5$ & $-13,3$ & $g$ & 8 & 0 & 23,3 & $-0,3$ & $g$ & 10 & 7 & 2,2 & 0 \\
\hline$g$ & 4 & 0 & 932,1 & $-1,6$ & $g$ & 8 & 1 & 7,3 & 0,6 & $h$ & 10 & 7 & $-2,4$ & 0 \\
\hline$g$ & 4 & 1 & 786,3 & 0,9 & $h$ & 8 & 1 & 12,4 & $-0,5$ & $g$ & 10 & 8 & 4,6 & 0 \\
\hline$h$ & 4 & 1 & 273,3 & 2,3 & $g$ & 8 & 2 & $-8,5$ & $-0,8$ & $h$ & 10 & 8 & 1,3 & 0 \\
\hline$g$ & 4 & 2 & 250,6 & $-7,6$ & $h$ & 8 & 2 & $-20,8$ & 0,1 & $g$ & 10 & 9 & 2,3 & 0 \\
\hline$h$ & 4 & 2 & $-227,9$ & 0,7 & $g$ & 8 & 3 & $-6,6$ & 0,3 & $h$ & 10 & 9 & $-2,3$ & 0 \\
\hline$g$ & 4 & 3 & $-401,5$ & 2,2 & $h$ & 8 & 3 & 8,4 & $-0,2$ & $g$ & 10 & 10 & 0,1 & 0 \\
\hline$h$ & 4 & 3 & 120,9 & 3,7 & $g$ & 8 & 4 & $-16,9$ & $-0,2$ & $h$ & 10 & 10 & $-6,4$ & 0 \\
\hline$g$ & 4 & 4 & 106,2 & $-3,2$ & $h$ & 8 & 4 & $-21,2$ & 0 & $g$ & 11 & 0 & 3,3 & 0 \\
\hline$h$ & 4 & 4 & $-302,7$ & $-0,5$ & $g$ & 8 & 5 & 8,6 & 0,5 & $g$ & 11 & 1 & $-1,1$ & 0 \\
\hline$g$ & 5 & 0 & $-211,9$ & $-0,9$ & $h$ & 8 & 5 & 15,5 & 0,1 & $h$ & 11 & 1 & $-1,5$ & 0 \\
\hline$g$ & 5 & 1 & 351,6 & $-0,2$ & $g$ & 8 & 6 & 4,9 & 0 & $g$ & 11 & 2 & $-2,4$ & 0 \\
\hline$h$ & 5 & 1 & 42 & 0 & $h$ & 8 & 6 & 9,1 & $-0,1$ & $h$ & 11 & 2 & 0,7 & 0 \\
\hline$g$ & 5 & 2 & 220,8 & $-2,5$ & $g$ & 8 & 7 & $-7,8$ & $-0,6$ & $g$ & 11 & 3 & 2,6 & 0 \\
\hline$h$ & 5 & 2 & $\begin{array}{ll}173,8 \\
\end{array}$ & 2,1 & $h$ & 8 & 7 & $-15,5$ & 0,3 & $h$ & 11 & 3 & $-1,1$ & 0 \\
\hline$g$ & 5 & 3 & $-134,5$ & $-2,7$ & $g$ & 8 & 8 & $-7,6$ & 0,1 & $g$ & 11 & 4 & $-1,3$ & 0 \\
\hline$h$ & 5 & 3 & -135 & 2,3 & $h$ & 8 & 8 & $-5,4$ & 0,2 & $h$ & 11 & 4 & $-2,3$ & 0 \\
\hline$g$ & 5 & 4 & $-168,8$ & $-0,9$ & $g$ & 9 & 0 & 5,7 & 0 & $g$ & 11 & 5 & $-1,7$ & 0 \\
\hline$h$ & 5 & 4 & $-38,6$ & 3,1 & $g$ & 9 & 1 & 8,5 & 0 & $h$ & 11 & 5 & 1,3 & 0 \\
\hline$g$ & 5 & 5 & $\begin{array}{l}-13,3 \\
\end{array}$ & 1,7 & $h$ & 9 & 1 & $-20,4$ & 0 & $g$ & 11 & 6 & $-0,6$ & 0 \\
\hline$h$ & 5 & 5 & 105,2 & 0 & $g$ & 9 & 2 & 2 & 0 & $h$ & 11 & 6 & $-0,6$ & 0 \\
\hline$g$ & 6 & 0 & 73,8 & 1,2 & $h$ & 9 & 2 & 13,9 & 0 & $g$ & 11 & 7 & 0,4 & 0 \\
\hline$g$ & 6 & 1 & 68,2 & 0,2 & $g$ & 9 & 3 & $-9,8$ & 0 & $h$ & 11 & 7 & $-2,8$ & 0 \\
\hline$h$ & 6 & 1 & $-17,4$ & $-0,3$ & $h$ & 9 & 3 & 12 & 0 & $g$ & 11 & 8 & 0,7 & 0 \\
\hline$g$ & 6 & 2 & 74,1 & 1,7 & $g$ & 9 & 4 & 7,6 & 0 & $h$ & 11 & 8 & $-1,6$ & 0 \\
\hline$h$ & 6 & 2 & 61,2 & $-1,7$ & $h$ & 9 & 4 & $-6,2$ & 0 & $g$ & 11 & 9 & $-0,3$ & 0 \\
\hline$g$ & 6 & 3 & $-163,5$ & 1,6 & $g$ & 9 & 5 & -7 & 0 & $h$ & 11 & 9 & $-0,1$ & 0 \\
\hline$h$ & 6 & 3 & 63,2 & $-0,9$ & $h$ & 9 & 5 & $-8,6$ & 0 & $g$ & 11 & 10 & 2,3 & 0 \\
\hline$g$ & 6 & 4 & $-3,8$ & $-0,1$ & $g$ & 9 & 6 & -2 & 0 & $h$ & 11 & 10 & $\begin{array}{l}-1,9 \\
\end{array}$ & 0 \\
\hline$h$ & 6 & 4 & $-62,9$ & -1 & $h$ & 9 & 6 & 9,4 & 0 & $g$ & 11 & 11 & 4,2 & 0 \\
\hline$g$ & 6 & 5 & 17,1 & $-0,3$ & $g$ & 9 & 7 & 9,2 & 0 & $h$ & 11 & 11 & 1,4 & 0 \\
\hline$h$ & 6 & 5 & 0,2 & $-0,1$ & $h$ & 9 & 7 & 5 & 0 & $g$ & 12 & 0 & $-1,5$ & 0 \\
\hline$g$ & 6 & 6 & $-85,1$ & 0,8 & $g$ & 9 & 8 & $-2,2$ & 0 & $g$ & 12 & 1 & $-0,2$ & 0 \\
\hline$h$ & 6 & 6 & 43 & 1,9 & $h$ & 9 & 8 & $-8,4$ & 0 & $h$ & 12 & 1 & -1 & 0 \\
\hline$g$ & 7 & 0 & 77,4 & $-0,4$ & $g$ & 9 & 9 & $-6,6$ & 0 & $g$ & 12 & 2 & $-0,3$ & 0 \\
\hline$h$ & 12 & 2 & 0,7 & 0 & $g$ & 12 & 6 & $-1,4$ & 0 & $h$ & 12 & 9 & 0,2 & 0 \\
\hline$g$ & 12 & 3 & 0,5 & 0 & $h$ & 12 & 6 & 0 & 0 & $g$ & 12 & 10 & $-0,3$ & 0 \\
\hline$h$ & 12 & 3 & 2,2 & 0 & $g$ & 12 & 7 & 0,6 & 0 & $h$ & 12 & 10 & $-0,9$ & 0 \\
\hline$g$ & 12 & 4 & 0,2 & 0 & $h$ & 12 & 7 & $-0,2$ & 0 & $g$ & 12 & 11 & 0,3 & 0 \\
\hline$h$ & 12 & 4 & $-2,5$ & 0 & $g$ & 12 & 8 & $-0,6$ & 0 & $h$ & 12 & 11 & $-0,2$ & 0 \\
\hline$g$ & 12 & 5 & 0,9 & 0 & $h$ & 12 & 8 & 0 & 0 & $g$ & 12 & 12 & 0,4 & 0 \\
\hline$h$ & 12 & 5 & $-0,2$ & 0 & $g$ & 12 & 9 & -1 & 0 & $h$ & 12 & 12 & 1 & 0 \\
\hline
\end{tabular}


WMM serijos modelis atnaujinamas kas 5-eri metai sausio 1 dieną. Atnaujinama tais metais, kurie dalijasi iš 5 (pvz., 1980, 1985, 1990). Šio modelio koeficientai redukuoti i WGS-84 elipsoidą.

Skaičiavimams naudojama WMM-00 programa. I programą įvedami tokie parametrai:

$A L T$ - geodezinis aukštis $(\mathrm{km})$;

GLAT - geodezinè platuma (laipsn.);

GLON - geodezinè ilguma (laipsn.);

DATE - laikas (epocha, kurios magnetinių elementu reikšmès skaičiuojamos).

Programa apskaičiuoja šias geomagnetinio lauko elementų reikšmes: deklinaciją - DEC (laipsn.), inklinaciją - DIP (laipsn.), magnetinio lauko jègos intensyvumą - $T I$ (nT) bei tų elementų kitimą per metus (chgDEC - minutès per metus; chgDIP - minutès per metus; chgTI-nT per metus).

Taikant modelį apskaičiuotų magnetinio lauko elementu sausumoje bei vandenynuose tikslumas yra skirtingas. Geomagnetinio lauko elementų tikslumas virš vandenynų:

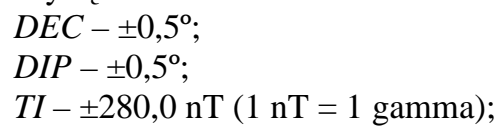

$X- \pm 140$ nT (šiaurès);

$Y- \pm 140$ nT (rytu);

$Z- \pm 200$ nT (vertikalioji);

$H- \pm 200 \mathrm{nT}$ (horizontalioji).

Parametrų nustatymo sausumoje klaidos kiek didesnès, tačiau, pagal modelių kūrèjų užtikrinimą, deklinacijų ir inklinacijų neviršija $1^{\circ}$ per ištisus 5 metus. Kitų elementų paklaidas nustatyti sunku, todèl jos nepateikiamos. Visų elementų tikslumas priklauso nuo geodezinès platumos. Nustatyta, kad mažiausios elementu paklaidos ties ekvatoriumi, didžiausios - ties magnetiniais poliais.

Modelyje neivertintas magnetosferos ir jonosferos poveikis amžių variacijoms.

\section{WMM-00 modelio tikslumas Lietuvos teritorijoje}

Lietuvos teritorijos WMM-00 modelio deklinacijos žemėlapis pavaizduotas 1 paveiksle. Geomagnetinio lauko modelio tikslumas ịvertintas dviem būdais: palyginus modelio skaičiavimo rezultatus su matavimų amžių variacijų punktuose duomenimis bei modelio skaičiavimo rezultatus - su atnaujinta 1940,5 m. epochos magnetine nuotrauka.

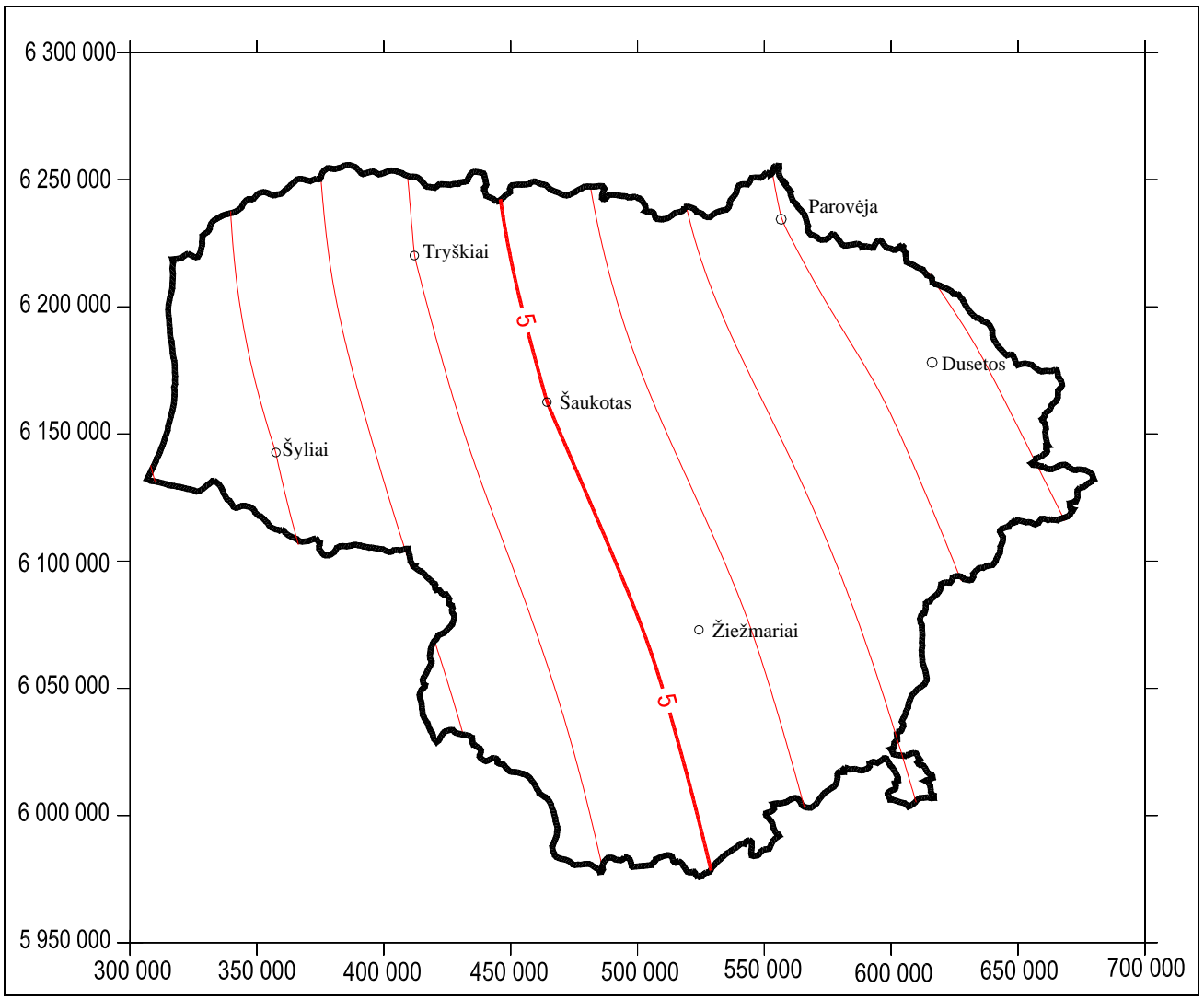

1 pav. 2000,5 m. epochos magnetinès deklinacijos žemėlapis pagal WMM-00 modeli

Fig 1. Magnetic declination map for 2000,5 epoch from WMM-00 model 
Pagal geomagnetinio lauko modeli apskaičiuotos 2000,5 m. epochos deklinacijos amžių variaciju punktuose reikšmès. Apskaičiuotosios reikšmès palygintos su amžių variacijų punktuose išmatuotomis ir redukuotomis į 2000,5 m. epochą deklinacijų reikšmėmis. Gauti deklinacijų skirtumai pateikti 2 lentelèje.

2 lentelè. 2000,5 m. epochos deklinacijos reikšmių, apskaičiuotų pagal modelị ir gautų atlikus matavimus, skirtumai Table 2. Differences between model and measured declination values for 2000,5 epoch

\begin{tabular}{|l|l|l|l|}
\hline & $\begin{array}{l}D \text { pagal } \\
\text { modeli } \\
\text { Punktas }\end{array}$ & $\begin{array}{l}D \text { pagal } \\
\text { matavimo } \\
\text { duomenis } \\
{ }^{\prime}, "\end{array}$ & Skirtumas \\
\hline ', " \\
\hline Žiežmariai & 506 & 60344 & +05744 \\
\hline Dusetos & 542 & 54455 & +00255 \\
\hline Parovėja & 536 & 53707 & +00107 \\
\hline Šaukotas & 500 & 41028 & -04932 \\
\hline Tryškiai & 448 & 50329 & +01529 \\
\hline Šyliai & 426 & 43018 & +00418 \\
\hline
\end{tabular}

Analizuojant gautus skirtumus matyti, kad modelio klaidos amžių variacijų punktuose siekia iki $1^{\circ}$. Didžiausi skirtumai yra Žiežmarių ir Šaukoto amžių punktuose, mažiausias - Parovèjos, čia pagal modeli apskaičiuotos reikšmès nuo gautų išmatavus skiriasi vos 1'.

Modelio tikslumas tirtas lyginant pagal modeli apskaičiuotas deklinacijos reikšmes su atnaujintos 1940,5 m. epochos deklinacijos nuotraukos reikšmėmis. 1940,5 m. epochos deklinacijos nuotrauka pagal Lenkijos Geodezijos ir kartografijos instituto specialistų sukurta metodiką atnaujinta i 2000,5 m. epochos [6]. Atnaujinta deklinacijos nuotrauka pavaizduota 2 paveiksle. Modelio tikslumui tirti Lietuvos teritorijoje imti 6 profiliai, kuriuose modelio duomenys palyginti su atnaujintos nuotraukos deklinacijos reikšmėmis. Profilių išdèstymas pavaizduotas 3 paveiksle. Deklinaciju skirtumai profiliuose - 4-9 paveiksluose.

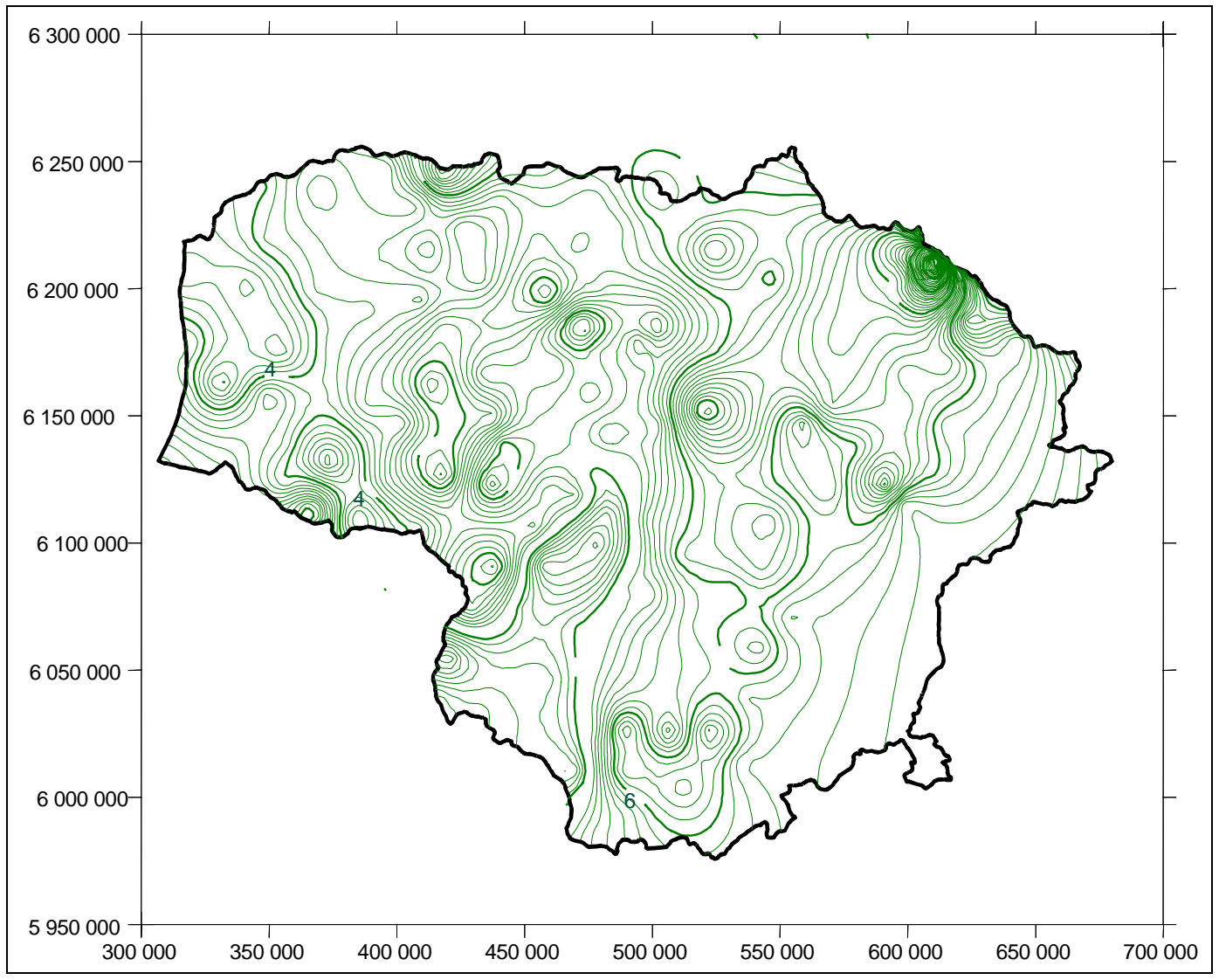

2 pav. 2000,5 m epochos magnetinès deklinacijos žemèlapis

Fig 2. Magnetic declination map for 2000,5 epoch 


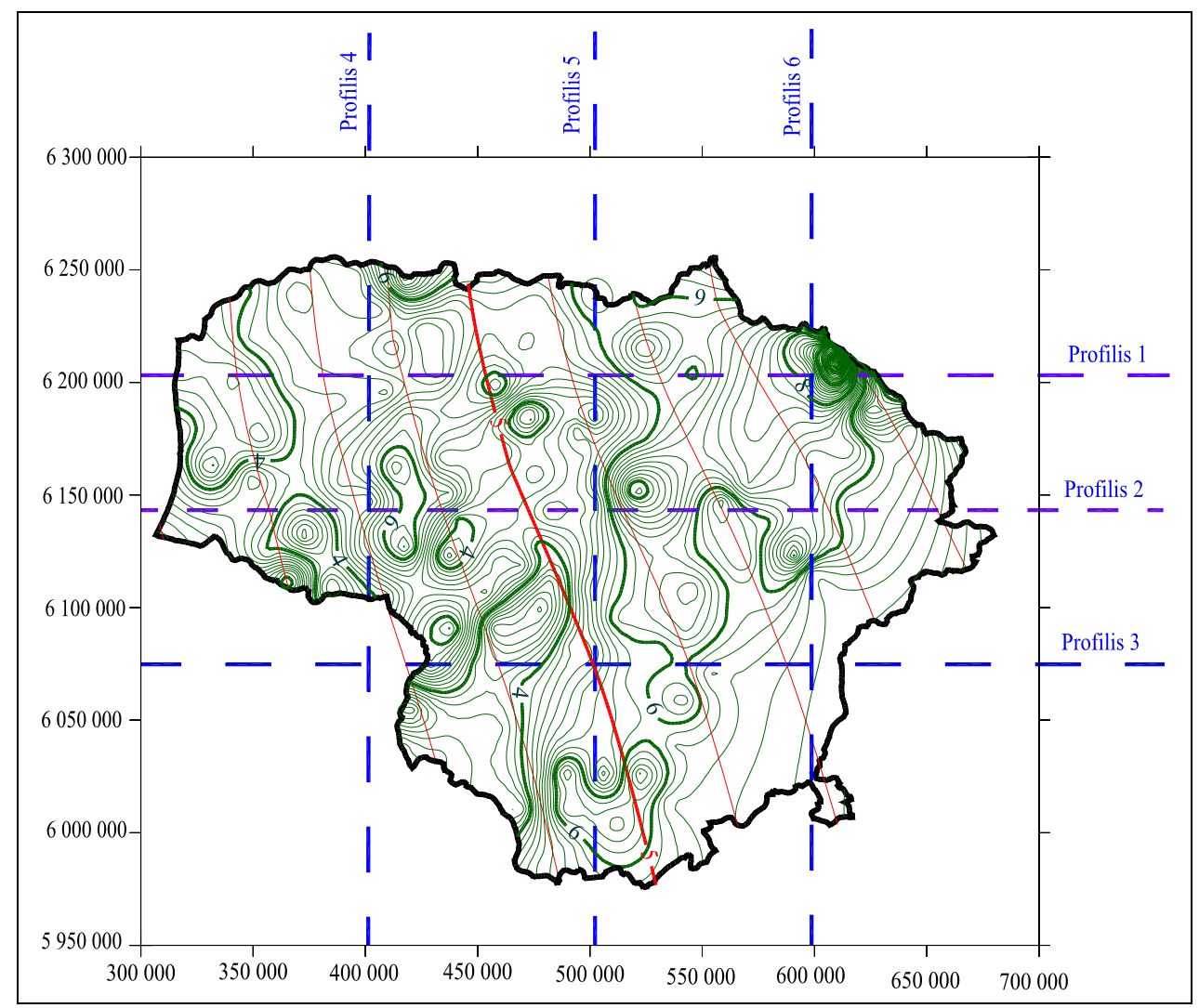

3pav. Profilių išdèstymas WMM-0 modelio tikslumui tirti

Fig 3. Profiles for analysis of WMM-0 model precision

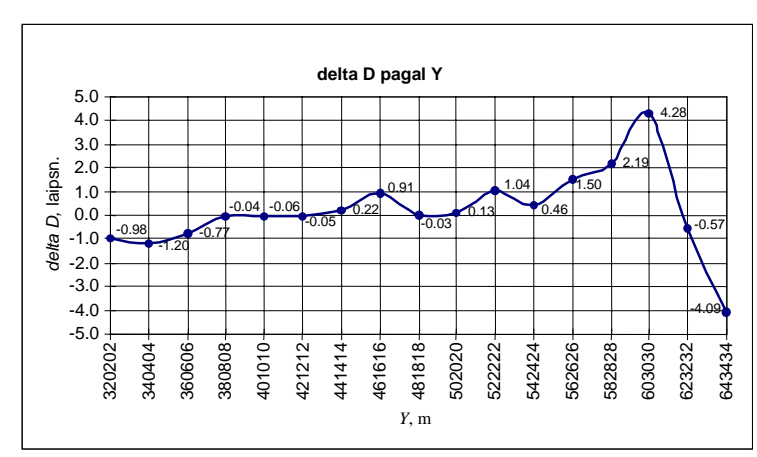

4 pav. Deklinacijos skirtumai profilyje 1

Fig 4. Declination differences in profile 1

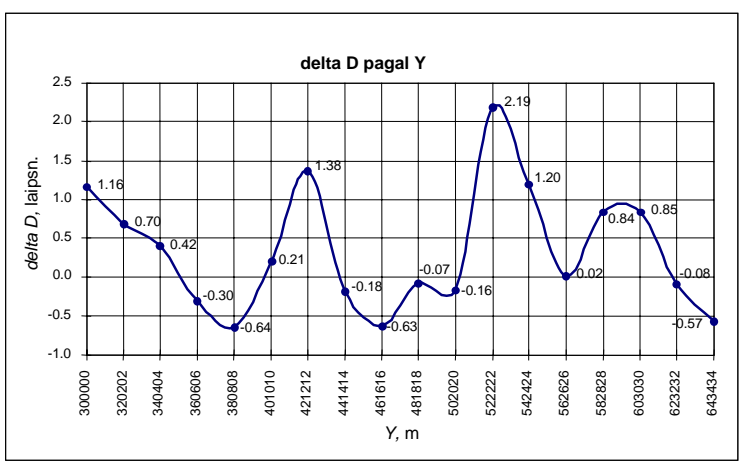

5 pav. Deklinacijos skirtumai profilyje 2

Fig 5. Declination differences in profile 2

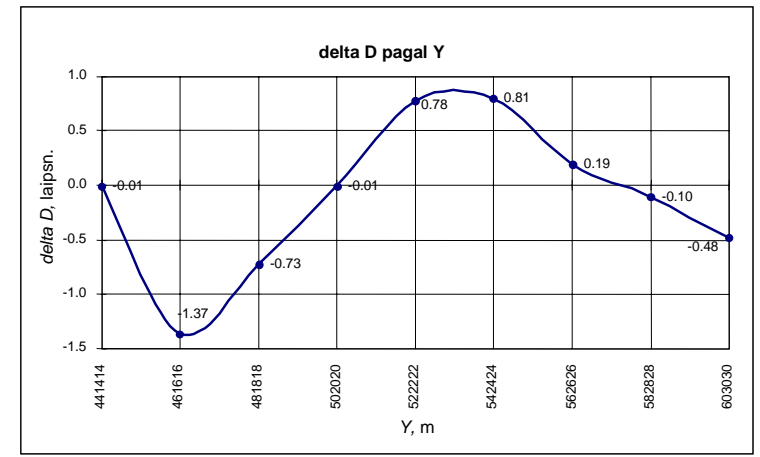

6 pav. Deklinacijos skirtumai profilyje 3 Fig 6. Declination differences in profile 3

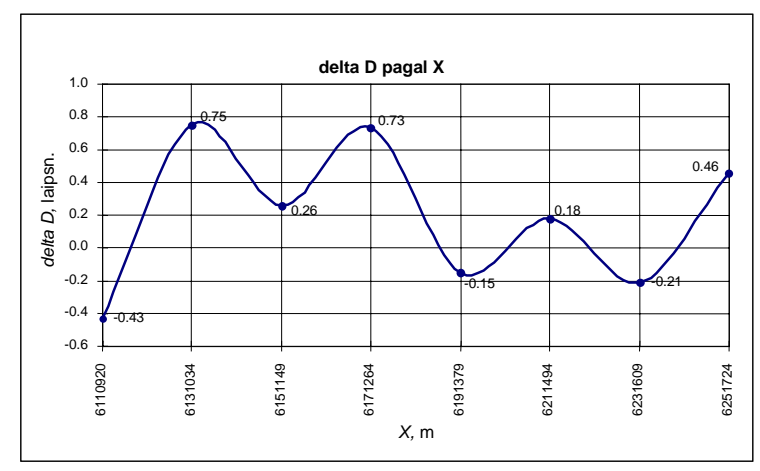

7 pav. Deklinacijos skirtumai profilyje 4

Fig 7. Declination differences in profile 4 


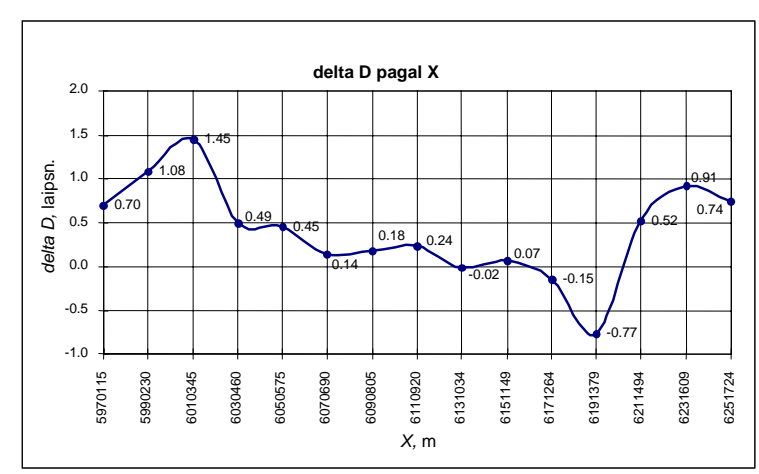

8 pav. Deklinacijos skirtumai profilyje 5

Fig 8. Declination differences in profile 5

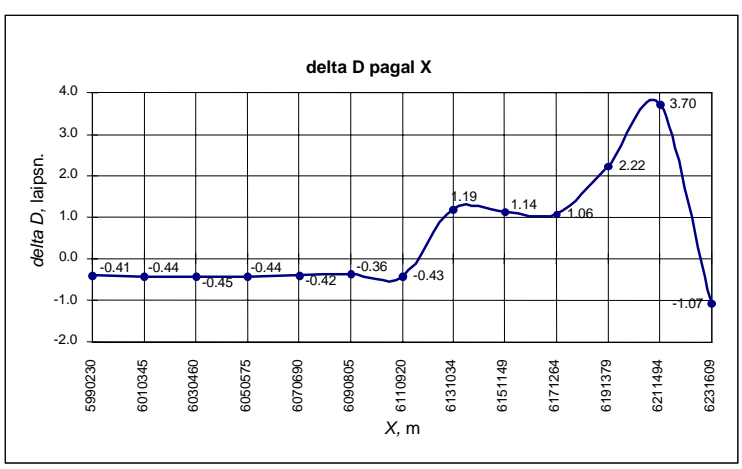

9 pav. Deklinacijos skirtumai profilyje 6

Fig 9. Declination differences in profile 6

Analizuojant modelio klaidas profiliuose matyti, kad modelio klaidos Lietuvos teritorijoje siekia iki $4^{\circ}$. Didžiausios modelio klaidos yra šalies ŠR dalyje.

\section{Išvados}

1. WMM-00 modelio deklinacijos Lietuvos teritorijoje paklaidos ištirtos dviem būdais: palyginus pagal modeli apskaičiuotas deklinacijos reikšmes su reikšmėmis, gautomis išmatavus amžių variaciju punktuose, bei modelio reikšmes palyginus su reikšmėmis atnaujintoje 1940,5 m. epochos deklinacijos nuotraukoje. Atlikus tyrimus matyti, kad WMM-00 modelio klaidos Lietuvos teritorijoje siekia $4^{\text {o }}$. Tokio tikslumo modelio duomenys gali būti naudojami tik geomagnetinio lauko apžvalginei analizei.
2. Būtina tęsti geomagnetinio lauko tyrimus amžių variaciju punktuose ir periodiškai kas 2-4 metai atlikti tikslius geomagnetinio lauko matavimus. Šie duomenys labai vertingi atnaujinant senus duomenis, tiriant geomagnetinio lauko pokyčius. Ypač tai svarbu teritorijose, kur retas magnetinių observatorijų tinklas.

3. Būtina atlikti naują Lietuvos teritorijos geomagnetinio lauko nuotrauką. Paskutini kartą tokia nuotrauka daryta daugiau kaip prieš šešiasdešimt metų ir yra jau pasenusi.

\section{Literatūra}

1. Merrill, R. T.; McElhinney, M. W. The Earth's Magnetic Field. London: Academic Press, 1983, p. 101-106.

2. Newitt, L. R.; Barton, C. E.; Bitterly, J. Guide to Magnetic Repeat Station Surveys. International Association of Geomagnetism and Aeronomy. Boulder, 1996. $126 \mathrm{p}$.

3. Haines, G. V. Regional Magnetic Field Modelling: a Review. Journal of Geomagnetism and Geoelectricity, 42, Tokyo, 1990, p. 1001-1018.

4. Macmillan, S.; Barraclough, D. R.; Quinn, J. M.; Coleman, R. J. The 1995 Revision of the Joint US/UK Geomagnetic Field Model - I. Secular Variation. Journal of Geomagnetism and Geoelectricity, 49, Tokyo, 1997, p. 229-243.

5. Quinn, J. M.; Coleman, R. J.; Macmillan, S.; Barraclough, D. R. The 1995 Revision of the Joint US/Uk Geomagnetic Field Models. II: Main Field. Journal of Geomagnetism and Geoelectricity, 49, Tokyo, 1997, p. 245-261.

6. Welker, E.; Sas-Uhrynowski, A.; Obuchovski, R. Changes of magnetic declination in the period of 1941-2000 at the former eastern Polish and near-by territories. Geodesy and Cartography (Geodezija ir kartografija), Vol XXIX, No 4. Vilnius: Technika, 2003, p. 107-114 (in Lithuanian). 